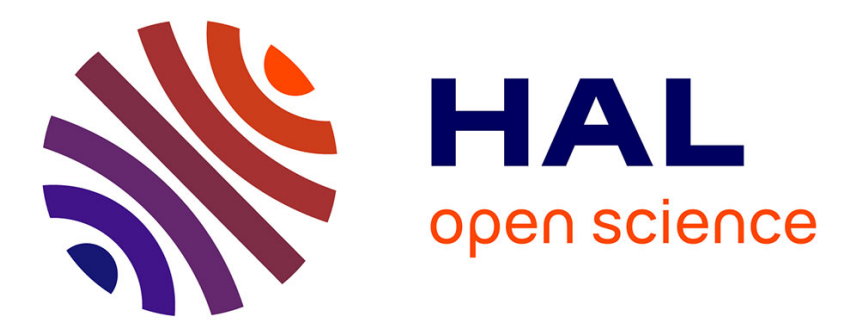

\title{
Additive-free selective methylation of secondary amines with formic acid over a $\mathrm{Pd} / \mathrm{In} \_2 \mathrm{O} \_3$ catalyst
}

Caroline Genre, Idir Benaissa, Timothé Godou, Mathieu Pinault, Thibault Cantat

\section{- To cite this version:}

Caroline Genre, Idir Benaissa, Timothé Godou, Mathieu Pinault, Thibault Cantat. Additive-free selective methylation of secondary amines with formic acid over a $\mathrm{Pd} / \mathrm{In} \_2 \mathrm{O} \_3$ catalyst. Catalysis Science \& Technology, In press, 12, pp.57-61. 10.1039/D1CY01626A . cea-03478547

HAL Id: cea-03478547 https://hal-cea.archives-ouvertes.fr/cea-03478547

Submitted on 14 Dec 2021

HAL is a multi-disciplinary open access archive for the deposit and dissemination of scientific research documents, whether they are published or not. The documents may come from teaching and research institutions in France or abroad, or from public or private research centers.
L'archive ouverte pluridisciplinaire HAL, est destinée au dépôt et à la diffusion de documents scientifiques de niveau recherche, publiés ou non, émanant des établissements d'enseignement et de recherche français ou étrangers, des laboratoires publics ou privés. 


\title{
Additive-free selective methylation of secondary amines with formic acid over a $\mathrm{Pd} / \mathrm{In}_{2} \mathrm{O}_{3}$ catalyst
}

\author{
Caroline Genre, ${ }^{* a}$ Idir Benaissa, ${ }^{a}$ Timothé Godou, ${ }^{a}$ Mathieu Pinault, ${ }^{a}$ and Thibault Cantat *a \\ a Université Paris-Saclay, CEA, CNRS, NIMBE, 91191 Gif-sur-Yvette (France). E-mail: caroline.genre@cea.fr; thibault.cantat@cea.fr
}

Electronic Supplementary Information (ESI) available. See DOI: 10.1039/D1CY01626A

\begin{abstract}
Formic acid is used as the sole carbon and hydrogen source in the methylation of aromatic and aliphatic amines to methylamines.
\end{abstract} The reaction proceeds via a formylation/transfer hydrogenation pathway over a solid $\mathrm{Pd} / \mathrm{In}_{2} \mathrm{O}_{3}$ catalyst without the need for any additive.

Methylamines are widely utilized compounds in both fine and bulk chemical industries. They are used as intermediates for the synthesis of agrochemicals, polymers, dyes, pharmaceuticals and are valuable organic building blocks. ${ }^{1}$ Methylation of an amine in a drug molecule can have a strong effect on its lipophilicity and potency. ${ }^{2}$ For these reasons, the development of methylation methods continues to attract the interest of chemists. The most common methods for synthesizing methylamines involve stoichiometric quantities of highly toxic methylating agents such as methyl iodide, formaldehyde, diazomethane or dimethylsulfate and generate abundant waste. ${ }^{3}$ In the quest for greener more sustainable reactions, catalytic methods utilizing renewable $\mathrm{C} 1$ sources $\left(\mathrm{CO}_{2}, \mathrm{HCOOH}(\mathrm{FA})\right.$, dimethyl carbonate) associated to reductants (silanes, boranes, $\mathrm{H}_{2}$ ) or additives (acids, salts) have been developed. ${ }^{4}$ Examples of such catalytic systems involve organometallic complexes of ruthenium ${ }^{5}$, zinc ${ }^{6}$, rhodium $^{7}$ or iron $^{8}$. Amines were successfully methylated by $\mathrm{CO}_{2} / \mathrm{H}_{2}$ over solid catalysts as well, such as CuAlOx${ }^{9}, \mathrm{Pt}-\mathrm{MoO}_{x} / \mathrm{TiO}_{2}{ }^{10}, \mathrm{PdGa}_{\mathrm{TiO}}{ }^{11}, \mathrm{Re} / \mathrm{TiO}{ }_{2}{ }^{12}$, or $\mathrm{Cu} / \mathrm{TiO}_{2}{ }^{13}$. These systems, however, require a high pressure of $\mathrm{H}_{2}$. This issue can be solved with the use of liquid $\mathrm{FA}$ instead of a mix of gases, as it can act as both a carbon source and a reductant. Moreover, a now mature technology has been developed to promote its synthesis from the 2-electron reduction of $\mathrm{CO}_{2}$ in an electrochemical cell over electro-catalysts, making $\mathrm{FA}$ a renewable reagent. ${ }^{14} \mathrm{~A}$ few heterogeneous catalysts have been described for the methylation of amines with FA. Kim and co-workers reported the successful additive-free methylation of aromatic amines with FA catalyzed by a supported PdAg alloy in $2015^{15}$. In 2016, Zhu et al. achieved this reaction over a Pd/C catalyst, albeit using hydrosilanes as reductants ${ }^{16}$. In order to expand the range of possible catalysts for this reaction, we sought to exploit the association of a catalyst known for its $\mathrm{CO}_{2}$ reduction activity and metal species active in reduction processes. We report here on the additive-free, one pot methylation of a variety of amines with an easily synthesized, water and air resistant catalyst. To our delight, we observed that Pd supported on indium oxide is active in the FA-mediated methylation of amines with yields up to $99 \%$.

$\mathrm{In}_{2} \mathrm{O}_{3}$ was recently shown to be a highly efficient and specific catalyst for the hydrogenation of $\mathrm{CO}_{2}$ to methanol. ${ }^{17}$ In a first attempt, we tested whether this oxide showed activity for the methylation of $p$-fluoro-N-methylaniline (1a) with FA (Table 1 , entry 2). The catalytic reaction was conducted in a sealed autoclave under atmospheric pressure. A low $p$-fluoro- $\mathrm{N}, \mathrm{N}$-dimethylaniline (1b) yield of about $11 \%$ was observed, as well as a $74 \%$ yield of $p$-fluoro- $\mathrm{N}$-methylformanilide $\left(\mathbf{1}\right.$ c). It thus appears that In $\mathrm{O}_{3}$ is capable of methylating $\mathbf{1 a}$ to $\mathbf{1 b}$ with FA but the activity remains low. For this reason, $\ln _{2} \mathrm{O}_{3}$-based catalysts doped with metals known for their hydrogenation properties ( $\mathrm{Pd}, \mathrm{Pt}, \mathrm{Ru}$ ) were synthesized and tested. The results are listed in Table 1 . The catalysts were synthesized by an impregnation technique followed by calcination of the resulting powder at $400^{\circ} \mathrm{C}$ for $3 \mathrm{~h}$ under air. Prereducing the catalysts $\left(20\right.$ bar $\left.\mathrm{H}_{2}, 200^{\circ} \mathrm{C}, 1 \mathrm{~h}\right)$ did not improve their activity nor their selectivity, therefore they were used as such. $\mathrm{GC}$ analysis of the atmosphere in the autoclave at the end of the reaction showed the presence of significant quantities of $\mathrm{H}_{2}$ and $\mathrm{CO}_{2}$ (Fig. S1). We thus postulate that in situ reduction of the catalysts was achieved from $\mathrm{H}_{2}$ resulting from the decomposition of FA over the catalyst. 
Table 1. Methylation of 4-fluoro-N-methylaniline (1a) with FA over various catalysts. ${ }^{\circ}$

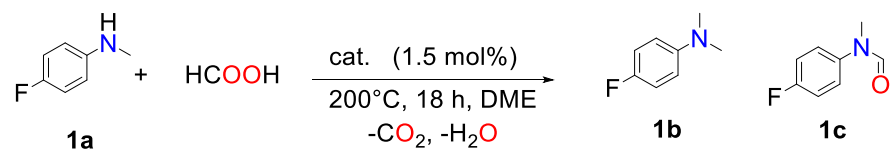

\begin{tabular}{|c|c|c|c|c|}
\hline Entry & Cat. & Conv. (\%) & Yield 1b (\%) & Yield 1c (\%) \\
\hline 1 & None & 97 & Traces & 96 \\
\hline 2 & $\mathrm{In}_{2} \mathrm{O}_{3}$ & 98 & 11 & 74 \\
\hline 3 & $\mathrm{Pd} / \mathrm{In}_{2} \mathrm{O}_{3}$ & 100 & 94 & 4 \\
\hline 4 & $\mathrm{Pd} / \mathrm{C}$ & 88 & 9 & 72 \\
\hline 5 & $\mathrm{Pt} / \mathrm{In}_{2} \mathrm{O}_{3}$ & 85 & 30 & 51 \\
\hline 6 & $\mathrm{Pt} / \mathrm{C}$ & 58 & 5 & 47 \\
\hline 7 & $\mathrm{Ru} / \mathrm{In}_{2} \mathrm{O}_{3}$ & 82 & 14 & 59 \\
\hline 8 & $\mathrm{Ru} / \mathrm{C}$ & 75 & 8 & 44 \\
\hline
\end{tabular}

a Reaction conditions: 1a (5 mmol), catalyst $1.5 \mathrm{~mol} \%$, FA (60 mmol), DME (10 mL), $200^{\circ} \mathrm{C}, 18 \mathrm{~h}$. Yields determined by GC/MS using isooctane as an internal standard, after calibration.

4-fluoro-N-methylaniline was retained as a benchmark substrate. Among the various catalysts tested, $\mathrm{Pd} / \mathrm{In}_{2} \mathrm{O}_{3}$ afforded the best activity for $\mathrm{N}$-methylation (yield: $94 \%$ ). Remarkably, $\mathrm{Pd} / \mathrm{In}_{2} \mathrm{O}_{3}$ showed better activity than both $\mathrm{In}_{2} \mathrm{O}_{3}$ and $\mathrm{Pd} / \mathrm{C}$, indicating that a positive synergistic effect occurs between the oxidic support and the Pd catalytic species. The same observation can be made with Ru and Pt containing catalysts (entries 5-8).

$\mathrm{Pd} / \mathrm{In}_{2} \mathrm{O}_{3}$ displays higher activity than the Pt and Ru containing analogues ( $100 \%$ conversion vs 85 and $82 \%$, respectively), and higher selectivity towards $\mathbf{1 b}$ ( $94 \%$ yield vs 30 and $14 \%$ respectively). The reaction conditions for the methylation of various amines were therefore optimized with this catalyst (see Table S1). When the reaction is conducted at $150^{\circ} \mathrm{C}$, there is total conversion of $\mathbf{1 a}$ but the yield in $\mathbf{1 b}$ is limited to $22 \%$ after $12 \mathrm{~h}$ (entry 2 ). The results are much better at $200^{\circ} \mathrm{C}$, with an $85 \%$ yield in the desired product. This is consistent with reports showing that $\ln _{2} \mathrm{O}_{3}$ is more active for $\mathrm{CO}_{2}$ hydrogenation above this temperature. ${ }^{17}$ Screening different solvents revealed that DME is the best suited for the methylation reaction (entry 1 ), while yields fall when the reaction is conducted in hexane (entry 3 ). With THF, significant degradation of the solvent is observed, making its use impractical (entry 4).

A $12 \mathrm{~h}$ reaction time with 4 -fluoro- $\mathrm{N}$-methylaniline as a substrate leads to a $100 \%$ conversion with a $85 \%$ yield of $\mathbf{1 b}$ (Table $\mathrm{S1}$, entry 1 ), which increased to $94 \%$ after 18 h (entry 5 ). Longer reaction times did not provide better yields (entry 6 ).

The quantity of FA relative to the substrate was also optimized. Tests were made with $2,4,8$ and 12 equivalents of FA (entries 5 and $7-9)$. The best conversion (100\% vs 58, 73, and 93\%, respectively) and 1 b yield (94\% vs 6,16 and $23 \%$ respectively) were obtained with 12 eq. FA (entry 5). This stoichiometry was thus selected for further catalytic reactions.

The $\mathrm{Pd} / \mathrm{In}_{2} \mathrm{O}_{3}$ catalyst is a brown powder that turns to black after it is reduced, and turns back to brown after it is annealed again, as would be the case in a typical recycling experiment. SEM-EDX mappings of a fresh catalyst sample show that Pd, In, and $\mathrm{O}$ are spread uniformly on a micrometric scale (Fig. S3). XPS spectra of the samples were recorded before and after reaction with a substrate, as well as after annealing under air of a spent catalyst sample. They confirmed the presence of In, Pd and $\mathrm{O}$ in the samples. In the as-prepared state, the Pd3d signal at $336.7 \mathrm{eV}$ is ascribed to PdO (Fig. S4). ${ }^{18}$ The In $3 \mathrm{~d}_{5 / 2}$ signal was detected at $444.1 \mathrm{eV}$, characteristic of $\operatorname{In}_{2} \mathrm{O}_{3}$ (Fig. S5) ${ }^{19}$. A shift of the $\mathrm{Pd} 3 \mathrm{~d}$ signal to $335.6 \mathrm{eV}$ is observed for the reacted catalyst sample, which according to literature corresponds to elemental Pd. ${ }^{18}$ After annealing of the spent catalyst, the Pd signal appeared at $337.3 \mathrm{eV}$, indicating a re-oxidation of palladium. In the reacted catalyst, the $\ln 3 \mathrm{~d}_{5 / 2}$ signal was recorded at $444.9 \mathrm{eV}$ and the peak became broader, signaling that while indium was not significantly reduced during the reaction, another chemical environment is present, possibly $\ln (\mathrm{OH})_{3}$. After annealing of the spent catalyst, the In signal was detected at $444.5 \mathrm{eV}$ and the peak became narrower again, signaling a return to $\ln _{2} \mathrm{O}_{3}$. The atomic concentration of $\mathrm{Pd}$ of the near surface region was $16.7 \%$ for the as-prepared catalyst and decreased to $4.1 \%$ in the spent catalyst (Table S2). It retained a similar value $(4.2 \%)$ over annealing $\left(400^{\circ} \mathrm{C}, 3 \mathrm{~h}\right)$ of the spent catalyst. 
HR-TEM images of samples of the fresh, reacted and recycled catalyst were recorded, as well as EDX spectra. The fresh Pd/In $\mathrm{O}_{3}$ materials is made of objects varying in size from about 20 to $50 \mathrm{~nm}$ aggregated into bigger objects (100-500 nm) (Fig S6a). The bigger objects seem to result from the aggregation of two different kinds of material (Fig. S6b). Close-ups of zones containing both types of material, (zones 1 and 2 on Fig. S6b) were recorded, and EDX analysis of both zones were carried-out. The material in zone 1 is highly crystalline, with the planes clearly visible (Fig. S6c). The EDX spectrum shows a high concentration of palladium in the material (Fig. S6d). A close up of zone 2 shows that the material is crystalline as well (Fig S6e). EDX showed a high concentration of indium and no palladium in this zone (Fig. S6f). We can deduct from these studies that fresh $\mathrm{Pd} / \mathrm{In}_{2} \mathrm{O}_{3}$ catalyst is likely made of particles of indium oxide decorated with palladium oxide. This is consistent with the catalyst synthesis method, where indium oxide is suspended in a solution containing $\mathrm{Pd}^{2+}$ ions before solvent evaporation and subsequent annealing.

A sample of the reacted catalyst was analyzed with similar methods. The reacted catalyst displays nanostructures with a 5-10 $\mathrm{nm}$ size aggregated into bigger objects (Fig S7a). The material is crystalline with the planes clearly visible. The material is much more homogeneous in nature than the fresh catalyst. EDX spectra of various zones of a number of different particles all confirmed the presence of both metals in every point of the sample (Fig. S7b). These results are consistent with observations reported by Neumann et al., who described the formation of intermetallic In-Pd particles, as well as diffusion of Pd into the bulk upon exposure of similar $\mathrm{Pd} / \mathrm{In}_{2} \mathrm{O}_{3}$ sample to reducing conditions at $200^{\circ} \mathrm{C} .{ }^{19}$ These observations, combined with the homogenization of the catalyst material most likely account for the decrease of the concentration of palladium observed by XPS.

A sample of reacted catalyst that was subsequently re-oxidized by annealing under air was observed with HR-TEM as well. The morphology is the same as with the reacted catalyst, with nanostructures of $c a .10 \mathrm{~nm}$ aggregated into bigger objects (Fig S8a). The material is still crystalline, and quite homogeneous. EDX analyses in various points of the sample showed that confirmed the presence of both In and Pd everywhere (Fig. S8b). This is consistent with the stable atomic concentration of Pd in the samples detected with XPS.

In order to ensure that there is no contribution from Pd possibly leached from the solid catalyst, our benchmark reaction was carried out with pure $\ln _{2} \mathrm{O}_{3}$ powder in the liquid phase recovered from a previous run of the reaction, but only extremely limited activity for amine methylation could be observed (3\%).

All these observations allow us to propose that $\mathrm{Pd}$ in the catalyst is reduced by either FA or $\mathrm{H}_{2}$ (produced upon FA decomposition), and that metallic Pd on In oxide and/or In-Pd intermetallic species are the active catalytic species.

Recycling experiments were carried out with 1a as a substrate (Fig. 1). After each run, the recovered catalyst was annealed under air at $400^{\circ} \mathrm{C}$ for $3 \mathrm{~h}$. Full conversion and excellent specificity were obtained with a second and third run of the catalyst. In a fourth run, specificity decreased to $85 \%$ of the desired product.

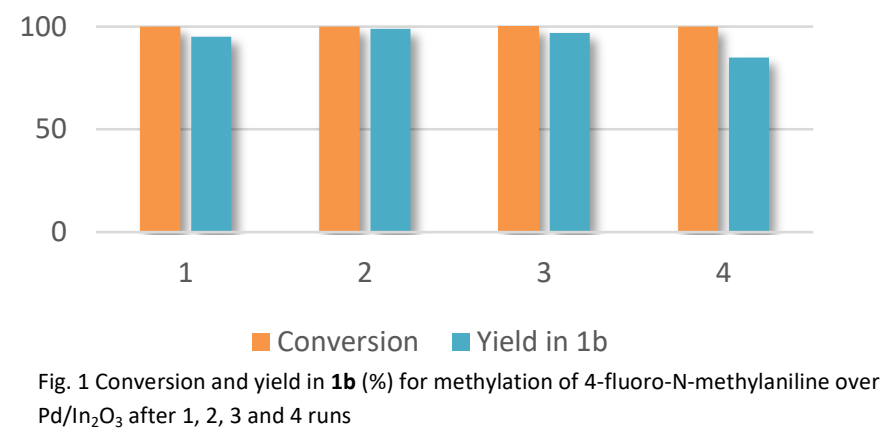

The methylation of a variety of primary and secondary amines was carried out to explore the potential of this novel catalytic transformation. Using 12 equivalents of FA, the methylation of secondary aromatic amines (entries 1-7) is efficient, with yields ranging between 70 and $93 \%\left(18 \mathrm{~h}, 200^{\circ} \mathrm{C}, 1.5 \mathrm{~mol} \%[\mathrm{Pd}]\right)$. The catalytic system tolerates a variety of substituents on the aromatic ring. Interestingly, no hydrogenation of the aromatic cycle was observed, as can be the case with other Pd containing catalysts during hydrogenation of aromatic species including amides ${ }^{20}$. With aniline and $\mathrm{N}$-methylaniline, coupling by-products, mostly 4,4'methylenebis( $N, N$-dimethylaniline), were observed, which explains the low yield in product 11b. The same kind of coupling was observed with 5a and 10a, yielding 4,4'-methylenebis(3-chloro- $N, N$-dimethylaniline) and 4,4'-methylenebis( $N$-isopropyl-Nmethylaniline) as side products. The catalytic system displayed limited activity with aliphatic amines (entries 9-13). The best yield was obtained with morpholine (60\%). With substrate $12 \mathrm{a}$, secondary products such as $\mathrm{N}, \mathrm{N}$-diethylbenzylamine and $\mathrm{N}$ isopropylbenzylamine are observed, driving down the yield in desired product $\mathbf{1 2 b}$. 
Table 2. $\mathrm{Pd} / \mathrm{In}_{2} \mathrm{O}_{3}$ catalyzed methylation of aromatic and aliphatic amines with $\mathrm{FA}$

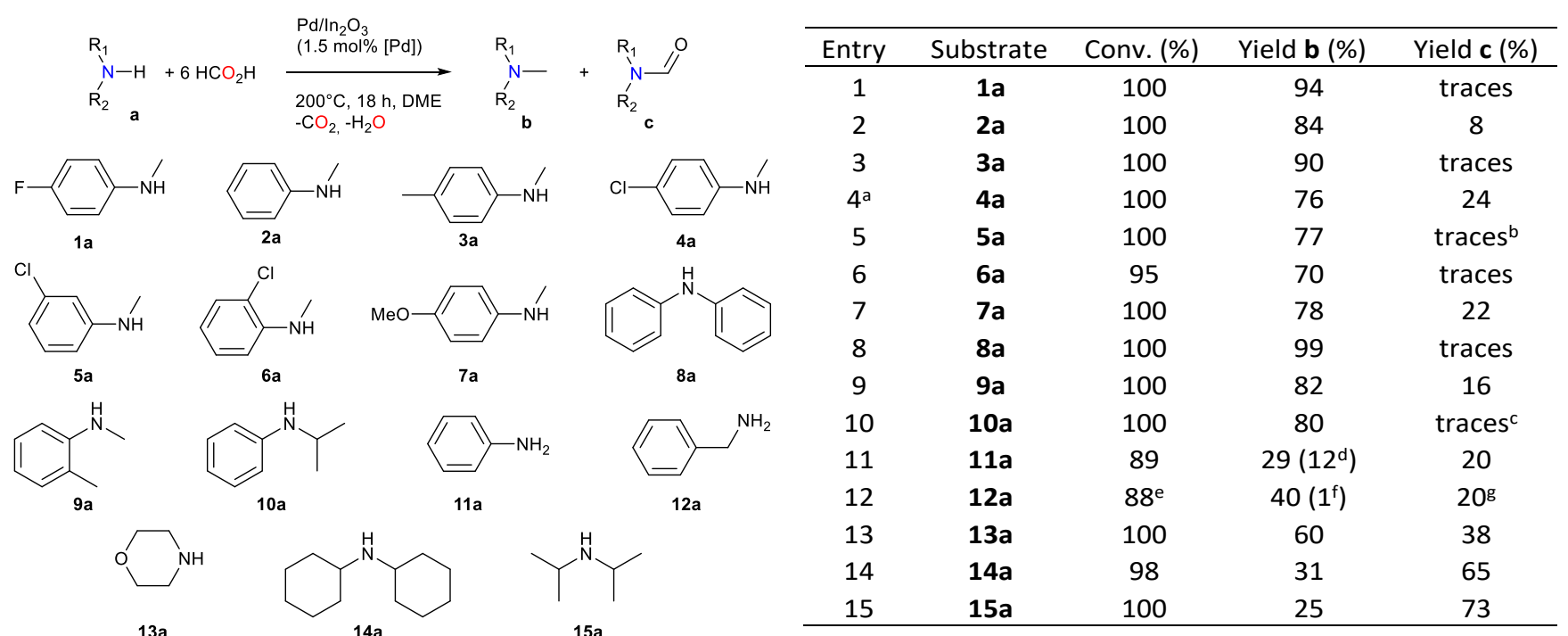

${ }^{a} 4.5$ mol\% catalyst; ${ }^{b}$ side-product: 4,4'-methylenebis(3-chloro- $\mathrm{N}, \mathrm{N}$-dimethylaniline) ${ }^{\mathrm{c}}$ side-product: methylenebis( $\mathrm{N}$-isopropyl-N-methylaniline) ${ }^{\mathrm{d}} \mathrm{N}$-methylaniline; ${ }^{\mathrm{e}}$ mix of various products including starting material and ethylated products; ${ }^{\text {f }} \mathrm{N}$-methylbenzylamine; ${ }^{\mathrm{g}}$ mix of $\mathrm{N}$-benzylformamide, $\mathrm{N}$-benzyl- $\mathrm{N}$-methylformamide, $\mathrm{N}$-benzyl- $\mathrm{N}$ formylformamide

With aromatic amines, products of methylation of the aromatic cycle were observed via Friedel-Crafts reaction: The reaction of $\mathrm{N}, \mathrm{N}$-dimethylaniline with $\mathrm{FA}$ over $\mathrm{Pd} / \mathrm{In}_{2} \mathrm{O}_{3}\left(\mathrm{DME}, 200^{\circ} \mathrm{C}, 18 \mathrm{~h}\right)$ yielded $15 \%$ of $\mathrm{N}, \mathrm{N}, 4$-trimethylaniline, $52 \%$ of 4,4 'methylenebis $(N, N$-dimethylaniline), and a mixture of various methylated derivatives of the latter (Scheme 1$)$. This is further indication that the reaction time must be chosen accurately to avoid over-methylation.

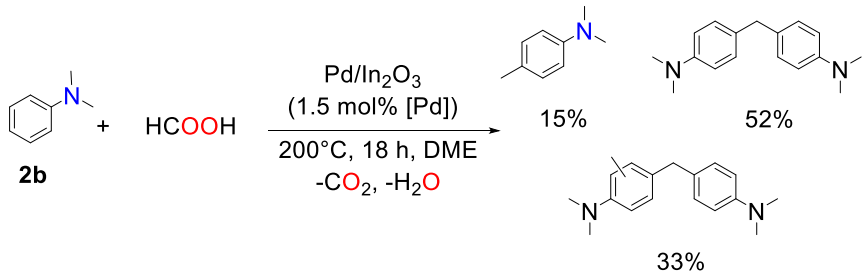

Scheme 1. Reaction of N,N-dimethylaniline with FA over Pd/In2O3

In light of these results, and in order to enhance the scope of this catalytic transformation, we investigated possible reaction pathways and intermediates. Based on the species detected at the end of the reaction, it quite plausible that the methylation of the $\mathrm{NH}$ function involves the formation of a formamide intermediate, which is subsequently reduced.

Reaction of $\mathrm{N}$-methylformanilide $2 \mathrm{c}$ with 12 equivalents of FA in our chosen conditions indeed provided $\mathrm{N}, \mathrm{N}$-dimethylaniline with an excellent $94 \%$ yield. A possible pathway is thus the conversion of the starting amine into the corresponding formamide, followed by either direct or transfer hydrogenation.

During the reaction, the pressure inside the autoclave increased to 30 bar. Gas chromatography analysis of the autoclave atmosphere confirms the presence of $\mathrm{H}_{2}$ and $\mathrm{CO}_{2}$, likely resulting from $\mathrm{FA}$ decomposition over the catalyst. It is thus possible that either FA or/and $\mathrm{H}_{2}$ are responsible for formamide (transfer)-hydrogenation. To test these hypotheses, the hydrogenation of $\mathrm{N}$ methylaformanilide was conducted in our preferred conditions with $\mathrm{FA}$ at $200^{\circ} \mathrm{C}$ and under a $\mathrm{H}_{2}$ and a $\mathrm{H}_{2} / \mathrm{CO}_{2}$ atmosphere. At 
$160^{\circ} \mathrm{C}$, conversion was extremely low, regardless the nature of the reductant, indicating that reduction of the amide is the rate determining step in the methylation of amines. A $>99 \%$ conversion and excellent $94 \%$ yield of $N, N$-dimethylaniline were obtained with FA as a reductant (Table 3, entry 1 ) at $200^{\circ} \mathrm{C}$. In contrast, the direct hydrogenation ( 30 bar $\mathrm{H}_{2}$ ) of $\mathrm{N}$-methylformanilide $\mathbf{2 c}$ provided a mixture of $\mathrm{N}$-methylaniline $\mathbf{2} \mathbf{a}$ and $\mathrm{N}, \mathrm{N}$-dimethylaniline $\mathbf{2} \mathbf{b}$ with a 50 to $60 \%$ yield depending on the conditions. This is consistent with recent results published by Sorribes et al., ${ }^{21}$ whereas only traces of the de-methylated product were observed with FA (Table 3, entries 2, 3). A higher $\mathrm{H}_{2}$ pressure (50 bar) did not significantly modify the results, and a $\mathrm{CO}_{2}$ pressure only had a marginal impact (Table 3, Entries 3,4 ). This leads us to propose that $F A$, and not $\mathrm{H}_{2}$ issued from its decomposition, is the principal reductant in the methylation of amines over $\mathrm{Pd} / \mathrm{In}_{2} \mathrm{O}_{3}$ (Fig. 2).

Methanol was observed in the reaction medium, as could be anticipated from the fact that $\ln _{2} \mathrm{O}_{3}$ catalyzes the hydrogenation of $\mathrm{CO}_{2}$ to methanol. The use of 4 equivalents of methanol as a methylating agent was tested with $N$-methylaniline in our preferred conditions. The reaction yielded a moderate $22 \%$ yield of methylated product (conversion: $30 \%$ ). It is thus possible that methanol issued from $\mathrm{CO}_{2}$ hydrogenation is a minor contributor to amine methylation as well.

Table 3. Hydrogenation of $\mathrm{N}$-methylformanilide with various reductants

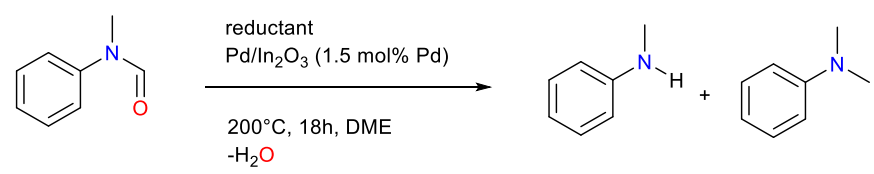

2c
\begin{tabular}{|c|c|c|c|c|c|}
\hline Entry & Reductant & $\begin{array}{c}\text { Pressure } \\
\text { (bar) }\end{array}$ & Conv. (\%) & $\begin{array}{c}\text { Yield 2a } \\
(\%)\end{array}$ & $\begin{array}{c}\text { Yield 2b } \\
(\%)\end{array}$ \\
\hline 1 & FA (12 eq) & - & $>99$ & Traces & 94 \\
\hline 2 & $\mathrm{H}_{2}$ & 30 & $>99$ & 32 & 60 \\
\hline 3 & $\mathrm{H}_{2}$ & 50 & $>99$ & 50 & 49 \\
\hline 4 & $\mathrm{H}_{2} / \mathrm{CO}_{2}$ & $30 / 30$ & $>99$ & 56 & 42 \\
\hline
\end{tabular}

${ }^{a}$ Reaction conditions: $1 \mathrm{a}(5 \mathrm{mmol}), \mathrm{Pd} / \mathrm{In}_{2} \mathrm{O}_{3} 80 \mathrm{mg}$, DME $(10 \mathrm{~mL}), 200^{\circ} \mathrm{C}, 18 \mathrm{~h}$. Yields determined by GC/MS using isooctane as an internal standard, after calibration.

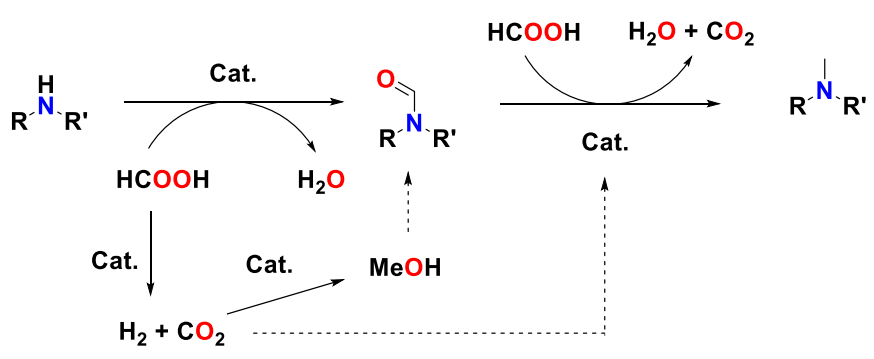

Figure 2. Proposed mechanism for the methylation of amines by FA

In conclusion, we have developed a simple, additive-free procedure for the $\mathrm{N}$-methylation of amines with $\mathrm{FA}$ as a carbon and hydrogen source, by using a water and air resistant $\mathrm{Pd} / \mathrm{In}_{2} \mathrm{O}_{3}$ catalyst, without the need for an additional reductant. Aromatic amines are methylated with good yields and no reduction of the aromatic cycle is observed.

\section{Conflicts of interest}

There are no conflicts of interest to declare. 


\section{Acknowledgments}

This work was supported by a grant from Fondation de la Maison de la Chimie (Paris, France). We acknowledge CEA, CNRS, and the European Research Council (ERC Consolidator Grant Agreement no. 818260) for financial support. The authors thank Dr Jocelyne Leroy (Université Paris-Saclay, CEA, CNRS, NIMBE - Gif-sur-Yvette, France) for the XPS measurements and Dr Éric Larquet (CIMEX, École Polytechnique, Palaiseau, France) for the HR-TEM imaging.

\section{References}

1. K. Weissermehl and H.-J. Arpe, Industrial Organic Chemistry, Wiley-VCH, 4th edn., 2003.

2. H.-G. Cheng, M. Pu, G. Kundu and F. Schoenebeck, Org. Lett., 2020, 22, 331-334.

3. M. B. Smith and J. March, March's Advanced Organic Chemistry, John Wiley \& Sons Inc, 5th edn., 2001.

4. (a)Y. Li, X. Cui, K. Dong, K. Junge and M. Beller, ACS Catal., 2017, 7, 1077-1086; (b)J. R. Cabrero-Antonino, R. Adam and M. Beller, Angew. Chem. Int. Ed., 2019, 58, 12820-12838; (c)J. R. Cabrero-Antonino, R. Adam, V. Papa and M. Beller, Nature Communications, 2020, 11, 3893.

5. (a)S. Savourey, G. Lefèvre, J.-C. Berthet and T. Cantat, Chem. Commun., 2014, 50, 14033-14036; (b)Y. Li, X. Fang, K. Junge and M. Beller, Angew. Chem. Int. Ed., 2013, 52, 9568-9571; (c)Y. Li, I. Sorribes, T. Yan, K. Junge and M. Beller, Angew. Chem. Int. Ed., 2013, 52, 12156-12160; (d)K. Beydoun, T. vom Stein, J. Klankermayer and W. Leitner, Angew. Chem. Int. Ed., 2013, 52, 9554-9557; (e)J. R. Cabrero-Antonino, R. Adam, K. Junge and M. Beller, Catal. Sci. Technol., 2016, 6, 7956-7966.

6. O. Jacquet, X. Frogneux, C. Das Neves Gomes and T. Cantat, Chem. Sci., 2013, 4, 2127-2131.

7. R. H. Lam, C. M. A. McQueen, I. Pernik, R. T. McBurney, A. F. Hill and B. A. Messerle, Green Chem., 2019, 21, 538-549.

8. X. Frogneux, O. Jacquet and T. Cantat, Catal. Sci. Technol., 2014, 4, 1529-1533.

9. X. Cui, X. Dai, Y. Zhang, Y. Deng and F. Shi, Chem. Sci., 2014, 5, 649-655.

10. K. Kon, S. M. A. H. Siddiki, W. Onodera and K.-i. Shimizu, Chem. Eur. J., 2014, 20, 6264-6267.

11. X. Su, W. Lin, H. Cheng, C. Zhang, Y. Li, T. Liu, B. Zhang, Q. Wu, X. Yu and F. Zhao, RSC Advances, 2016, 6, 103650-103656.

12. T. Toyao, S. M. A. H. Siddiki, Y. Morita, T. Kamachi, A. S. Touchy, W. Onodera, K. Kon, S. Furukawa, H. Ariga, K. Asakura, K. Yoshizawa and K.-i. Shimizu, Chem. Eur. J., 2017, 23, 14848-14859.

13. K. Liu, Z. Zhao, W. Lin, Q. Liu, Q. Wu, R. Shi, C. Zhang, H. Cheng, M. Arai and F. Zhao, ChemCatChem, 2019, 11, 3919-3926.

14. S. C. Perry, P.-k. Leung, L. Wang and C. Ponce de León, Curr. Opin. Electrochem., 2020, 20, 88-98.

15. A. K. Singh, Y.-H. Hwang and D.-P. Kim, NPG Asia Mater., 2015, 7, e222.

16. L. Zhu, L.-S. Wang, B. Li, W. Li and B. Fu, Catal. Sci. Technol., 2016, 6, 6172-6176.

17. O. Martin, A. J. Martín, C. Mondelli, S. Mitchell, T. F. Segawa, R. Hauert, C. Drouilly, D. Curulla-Ferré and J. Pérez-Ramírez, Angew. Chem. Int. Ed., 2016, 55, 6261-6265.

18. M. Brun, A. Berthet and J. C. Bertolini, J. Electron. Spectrosc. Relat. Phenom., 1999, 104, 55-60.

19. M. Neumann, D. Teschner, A. Knop-Gericke, W. Reschetilowski and M. Armbrüster, J. Catal., 2016, 340, 49-59.

20. M. Stein and B. Breit, Angew. Chem. Int. Ed., 2013, 52, 2231-2234.

21. I. Sorribes, S. C. S. Lemos, S. Martín, A. Mayoral, R. C. Lima and J. Andrés, Catal. Sci. Technol., 2019, 9, 6965-6976. 